\title{
Prenatal radiation exposure in diagnostic and interventional radiology
}

\section{Pränatale Strahlenexposition in der diagnostischen und interventionellen Radiologie}

Authors

Martin Fiebich ${ }^{1}$, Andreas Block ${ }^{2}$, Markus Borowski ${ }^{3}$, Lilli Geworski ${ }^{4}$, Christian Happel ${ }^{5}$, Alexandra Kamp ${ }^{6}$, Horst Lenzen ${ }^{7}$, Andreas H. Mahnken ${ }^{8}$, Wolfgang-Ulrich Müller ${ }^{9}$, Gebhard Östreicher ${ }^{10}$, Frank Rudolf ${ }^{4}$, Georg Stamm ${ }^{11}$, Peter Starck ${ }^{12}$, Beatrice Steiniger ${ }^{13}$, Jan-Henryk Wicke ${ }^{4}$, Ulrich Wolf ${ }^{14}$, Michael Wucherer ${ }^{15}$, Maria Zankl ${ }^{16}$, Klemens Zink ${ }^{1}$, Claudia Zweig ${ }^{17}$

\section{Affiliations}

1 Institute of Medical Physics and Radiation Protection, University of Applied Sciences Giessen, Germany

2 Institute for Medical Radiation Physics and Radiation Protection, Hospital of Dortmund gGmbH, Dortmund, Germany

3 Institute of Radiology and Nuclear Medicine, Municipal Hospital Braunschweig, Germany

4 Department of medical physics and radiation protection, Hannover Medical School, Hannover, Germany

5 Department of Nuclear Medicine, Goethe University Frankfurt; University Hospital, Frankfurt am Main, Germany

6 Department Medical and Occupational Radiation Protection, Federal Office for Radiation Protection Neuherberg, Germany

7 Department of Clinical Radiology, University Hospital Münster, Germany

8 Department of Diagnostic and Interventional Radiology, Phillips University Marburg; Marburg University Hospital, Marburg, Germany

9 Institute of Medical Radiation Biology, University Hospital Essen, Germany

10 Medical Physics and Radiation Protection, University Hospital Augsburg, Germany

11 Department of Diagnostic and Interventional Radiology, University Medical Center Göttingen, Göttingen, Germany

12 Institute of Diagnostic and Interventional Radiology, Medical Physics, Städtisches Klinikum Karlsruhe gGmbH, Karlsruhe, Germany

13 Department of Diagnostic and Interventional Radiology, Jena University Hospital, Jena, Germany

14 Department of Radiation Oncology, University Hospital Leipzig, Germany

15 Institute of Medical Physics, Nuremberg General Hospital, Paracelsus Medical University, Nuremberg, Germany

16 Institute of Radiation Medicine, Helmholtz Zentrum München German Research Center for Environmental Health, Neuherberg, Germany
17 Clinic for Radiooncology and Radiotherapy; Department Medical Radiological Physics, Hospital Carl-Thiem-Klinikum Cottbus gGmbH, Cottbus, Germany

Key words

radiation effects, pregnancy, dose assessment, radiation exposure

received 08.06.2020

accepted 04.11.2020

published online 16.12 .2020

Bibliography

Fortschr Röntgenstr 2021; 193: 778-786

DOI $10.1055 / \mathrm{a}-1313-7527$

ISSN 1438-9029

(c) 2020. Thieme. All rights reserved.

Georg Thieme Verlag KG, Rüdigerstraße 14,

70469 Stuttgart, Germany

Correspondence

Prof. Martin Fiebich

Inst. of Medical Physics, University of Applied Sciences

Giessen, Wiesenstr. 14, 35390 Gießen, Germany

Tel.: $+49 / 641 / 3092573$

Fax: $+49 / 641 / 3092914$

martin.fiebich@|se.thm.de

\section{ABSTRACT}

Background The exposure of a pregnant woman to X-rays is an event that can cause uncertainty for all concerned. This review provides guidance on how to assess such a situation and how to determine the dose to the unborn child. In general, the use of X-rays in pregnant women in radiology should be avoided. If possible, alternatives should be used, or examinations postponed to a time after the pregnancy. This review gives a summary of the procedure for determining the radiation exposure of a pregnant woman.

Method Based on the previous report of 2002 and the literature on prenatal radiation exposure published thereafter, the DGMP/DRG report on the procedure for the assessment of 
prenatal radiation exposure was adapted to the current state of science and technology.

Results Typically, only relatively low radiation exposures of less than 20 mSv occur for the unborn child in X-ray diagnostics in the vast majority of cases. At these dose level the additional risk of damage to the embryo or fetus caused by the radiation is low and therefore only a rough conservative estimate using tabulated values are made. Only in a few types of examination (CT and interventional radiology) higher doses values might occur in the uterus. Instead of dose estimates (step 1 in the two-step model) in these cases the calculation of dose (step 2) are required and further action by the physician may be necessary.

Conclusions During the assessment, it is useful to initially use simple conservative estimation procedures to quickly determine whether a case falls into this large group less than $20 \mathrm{mSv}$, where there is a very low risk to the unborn child. If this is the case, the pregnant woman should be informed immediately by the doctor who performed the examination/ treatment. This avoids a psychological burden on the patient. The DGMP/DRG report suggests a relatively simple, clearly structured procedure with advantages for all parties involved (physician, medical physics experts, MTRA and patient).

\section{Key points:}

- The DGMP/DRG report on prenatal radiation exposure describes the procedure for calculating radiation exposures and the associated risks for the unborn child.

- Using the two-step model, only a simple assessment based on the first step is necessary for most prenatal radiation exposures.

- With the given tables it is possible to estimate individual risks for the unborn child taking into account the radiation exposure.

- Only in the rare case that the first estimate results in a uterine dose larger $20 \mathrm{mSv}$ a more accurate calculation is necessary.

\section{Citation Format}

- Fiebich M, Block A, Borowski M et al. Prenatal radiation exposure in diagnostic and interventional radiology. Fortschr Röntgenstr 2021; 193: 778-786

\section{ZUSAMMENFASSUNG}

Hintergrund Die Exposition einer Schwangeren mit Röntgenstrahlung ist ein Ereignis, das bei allen Beteiligten Unsicherheit hervorrufen kann. Diese Übersichtsarbeit gibt Hinweise, wie eine derartige Situation zu bewerten ist und wie die Dosis für das ungeborene Kind ermittelt werden kann. Generell gilt, dass die Anwendung von Röntgenstrahlung bei Schwangeren in der Radiologie möglichst vermieden, Alternativen genutzt oder die Anwendung auf einen Zeitpunkt nach der Schwangerschaft verschoben werden sollen. Diese Übersichtsarbeit gibt eine Zusammenfassung der Vorgehensweise zur Bestimmung der Strahlenexposition einer Schwangeren.

Methode Auf Basis des Vorgängerberichts von 2002 und der danach publizierten Literatur zur pränatalen Strahlenexposition wurde der DGMP/DRG-Bericht zur Vorgehensweise bei der Bewertung der pränatalen Strahlenexposition dem Stand von Wissenschaft und Technik angepasst.

Ergebnisse Typischerweise treten in der Röntgendiagnostik in den überwiegend meisten Fällen nur relativ geringe Strahlenexpositionen kleiner als 20 mSv für das Ungeborene auf. Bei diesen Dosen ist das durch die Strahlung erzeugte zusätzliche Risiko für eine Schädigung des Embryos bzw. des Fötus gering und daher erfolgt hier nur eine grobe konservative Abschätzung nach Tabellenwerten. Nur bei wenigen Untersuchungsarten (CT oder interventionelle Radiologie) können höhere Werte der Uterusdosis erreicht werden. Statt der Dosisabschätzungen (Stufe 1 im 2-Stufen-Modell) sind in diesen Fällen Berechnungen (Stufe 2) zur Bestimmung der Dosis erforderlich und ggf. auch weitergehende Handlungen der Ärztin/des Arztes notwendig.

Schlussfolgerungen Es ist sinnvoll, bei der Bewertung zunächst mit einfachen konservativen Abschätzverfahren schnell festzustellen, ob ein Fall in diese große Gruppe kleiner als 20 mSv fällt, bei der eine sehr geringe Gefährdung des Embryos oder Fötus vorliegt. Ist dies der Fall, so soll die Schwangere von der Ärztin/dem Arzt, die/der die Untersuchung/Behandlung durchgeführt hat, sogleich davon unterrichtet werden. Dies vermeidet eine psychologische Belastung der Patientin. Der DGMP/DRG-Bericht schlägt ein relativ einfaches, klar strukturiertes Vorgehen vor, mit entsprechenden Vorteilen für alle Beteiligten (Arzt, Medizinphysik-Experten, MTRA und Patient).

\section{Introduction}

Medical radiation exposure of a pregnant patient is an infrequent but recurrent event. If radiation exposure of a pregnant woman is planned, it should always be carried out with the lowest possible exposure for the fetus. For example, in addition to the usual methods of dose reduction, positioning the unborn child close to the detector can be advantageous by varying the positioning of the pregnant woman on her stomach. In order to know prior to the examination whether a patient is pregnant, the German Radiation
Protection Ordinance [1] requires women of childbearing age to be queried regarding the possibility of a pregnancy. If pregnancy exists or cannot be ruled out, the urgency of the examination must be reviewed.

When a pregnant woman is exposed to X-rays, the question arises as to the probability of pregnancy complications, congenital malformations, mental and developmental retardation as well as mutagenic and carcinogenic effects occurring in the unborn child as a result of radiation exposure. Assessment of the planned application is always based on balancing the benefits of the exa- 
mination for the mother against the radiobiological risk for the mother and the fetus. Based on radiobiological principles, the Committee for Radiation Protection of the German Radiological Society developed a multi-step concept for the assessment of radiation exposure of pregnant women in 1980 [2]. Using this concept, the dosage is roughly estimated. A more precise calculation is made above a very low dose threshold of $20 \mathrm{mSv}$, thus ensuring that even if errors have occurred in the rough estimate of the dose, the unborn child has not yet been exposed to radiation that could have consequences from a radiobiological point of view. The vast majority of all radiation exposure in X-ray diagnostics is below this low dose threshold, therefore a more exact and somewhat more complex calculation is necessary in only a few cases.

The selected dose thresholds are based on radiobiological findings which are explained in more detail below.

This review article summarizes the detailed DGMP/DRG report on prenatal radiation exposure [3], which was fundamentally revised in 2019 and adapted to the state of the art. Please refer to this report for further explanations.

This review article is aimed at physicians, medical physics experts and radiological technicians; the practical estimation of the uterine dose above the first step should be reserved for competent radiologist physicians and medical physicists in radiology. A more detailed description including instructions for the application of the second step can be found in the newly revised DGMP/ DRG report on prenatal radiation exposure of 2019 [3].

\section{Possible effects after prenatal radiation exposure}

The evaluation of prenatal radiation exposure has occupied clinics and science for decades, resulting in extensive scientific literature on the subject. Detailed descriptions were provided by the Commission on Radiological Protection [4], UNSCEAR [5] and can be found in several ICRP publications [6-8].

Prenatal development of humans is characterized by cell division and multiplication, the specialization of cells and cell migration. These processes can be interrupted by ionizing radiation, resulting in a comparatively high radiation sensitivity of the embryo or fetus during its entire intrauterine development. The probability and consequences of radiation exposure differ considerably depending on the type and level of radiation, as well as the stage of prenatal development at exposure. The development of the fetus in the womb is often divided into three major stages of development: pre-implantation phase $\left(1^{\text {st }}-2^{\text {nd }}\right.$ week after conception, post-conception (p.c.)), organ formation phase $\left(3^{\text {rd }}-8^{\text {th }}\right.$ week p. c.) and fetal phase (from $9^{\text {th }}$ week p. c.). Simply stated, radiation sensitivity of the embryo/fetus is highest in the first trimester and then decreases.

In animal experiments [5-7] - especially on mice and rats - the dose-response relationships were determined for a large number of radiation effects in the development phases listed above. Some of the related data could be checked and verified through observation on humans. In other cases, the animal experiment results were extrapolated to dose-response relationships in humans.
Four effect categories are particularly important regarding prenatal radiation exposure from medical procedures: (1) pregnancy complications (spontaneous abortion, stillbirth), (2) congenital malformations, (3) mental and developmental retardation and (4) mutagenic and carcinogenic effects.

Sigmoidal dose-response relationships were observed for the occurrence of lethality, malformations and mental retardation. Threshold values for exposures below which the respective effects were not observed were estimated from these dose-response relationships. The slope of the curves above the threshold values enables the relative probability to be estimated as a function of the dose above the threshold value. The dose-response relationships are often not linear, so this is only an approximation. According to the current state of knowledge, the development of hereditary defects and development of cancer do not have a threshold dose, and are described in radiation protection by linear dose-effect curves, among other things, due to uncertainties in the dose-response relationship in the low-dose range.

- Table 1 shows an overview of possible non-malignant effects, the relevant time period after conception, the effects in several dose ranges, threshold values of the dose for the occurrence of an effect and currently assumed risk coefficients that can be expected for radiation exposures above the threshold values.

Radiation exposure during the pre-implantation phase either leads to the death of the embryo before implantation or implantation takes place normally and without negative consequences for the later organism. Such effects are usually not recognized in humans because the existence of a pregnancy at this stage is generally not yet known. Based on corresponding animal studies, the 1986 UNSCEAR Report [5] assigns a risk of $0.1 \%$ per mSv to this effect.

Exposure to radiation during the organ formation phase can cause anatomical malformations, inhibit growth and also cause functional disorders. Experimental studies show that there are threshold doses of at least $100 \mathrm{mSv}$ for these effects to occur. Based on data collected from atomic bomb survivors in Hiroshima and Nagasaki, it can be expected that the threshold doses are higher in humans. The data from Hiroshima and Nagasaki mainly show a reduced head circumference in children born after prenatal radiation exposure with doses above approx. $500 \mathrm{mSv}$.

Animal experiments show that the probability of malformations increases by $0.05 \%$ per mSv above the threshold value. UNSCEAR [5] postulates that this could also apply to humans for the entire period of the organ formation phase. A doubling of the probability of malformations is assumed in the dose range of about $200 \mathrm{mSv}$ [6].

Studies on children exposed to prenatal radiation from the atomic bombs in Japan have shown an increasing amount of severe mental retardation. However, this only occurred in children who were exposed between the $9^{\text {th }}$ and $25^{\text {th }}$ week p. c. Analyses show threshold doses between about 550 and $870 \mathrm{mSv}$; the lower $95 \%$ confidence interval is about $300 \mathrm{mSv}$ [9]. The risk coefficient is assumed to be $0.04 \%$ per mSv for exposure to X-rays between the $9^{\text {th }}$ and $15^{\text {th }}$ week p.c. and $0.01 \%$ per mSv between the $16^{\text {th }}$ and $25^{\text {th }}$ week [9]. 
- Table 1 Possible radiation-induced non-malignant health effects of intrauterine radiation exposure to low-LET radiation depending on the stage of development. The dose values given are the uterine dose (organ equivalent dose) for external photon radiation.

\begin{tabular}{|c|c|c|c|c|c|}
\hline $\begin{array}{l}\text { stage of } \\
\text { development }\end{array}$ & $\begin{array}{l}\text { approximate time } \\
\text { frame post-conception }\end{array}$ & $\leq 20 \mathrm{mSv}$ & $>20-100 \mathrm{mSv}$ & $>100 \mathrm{mSv}$ & $\begin{array}{l}\text { risk coefficient } \\
\text { per dose* }\end{array}$ \\
\hline $\begin{array}{l}\text { pre-implantation } \\
\text { phase }\end{array}$ & $1^{\text {st }}-2^{\text {nd }}$ week & none & $\begin{array}{l}\text { no evidence of sponta- } \\
\text { neous abortion to date }\end{array}$ & abortion possible & $0.1 \%$ per mSv \\
\hline \multirow[t]{2}{*}{ organogenesis } & $3^{\text {rd }}-8^{\text {th }}$ week & none & $\begin{array}{l}\text { Possible EFFECTS not } \\
\text { clinically detectable }\end{array}$ & $\begin{array}{l}\text { congenital } \\
\text { malformation }\end{array}$ & $0.05 \%$ per mSv \\
\hline & & & & $\begin{array}{l}>200 \text { mSv develop- } \\
\text { mental retardation }\end{array}$ & \\
\hline \multirow[t]{5}{*}{ fetogenesis } & $9^{\text {th }}-15^{\text {th }}$ week & $\begin{array}{l}\text { IQ reduction highly } \\
\text { unlikely }\end{array}$ & IQ reduction & IQ reduction & 0.03 IQ per $\mathrm{mSV}$ \\
\hline & & & & $\begin{array}{l}>300 \text { mSv severe } \\
\text { mental retardation }\end{array}$ & $0.04 \%$ per mSv \\
\hline & $16^{\text {th }}-25^{\text {th }}$ week & & IQ reduction & IQ reduction & $0.01 \mathrm{IQ}$ per $\mathrm{mSV}$ \\
\hline & & & & $\begin{array}{l}>300 \text { mSv severe } \\
\text { mental retardation }\end{array}$ & $0.01 \%$ per $\mathrm{mSv}$ \\
\hline & $>27^{\text {th }}$ week & \multicolumn{4}{|c|}{ no detectable effects in diagnostic range } \\
\hline
\end{tabular}

Furthermore, a reduction of the intelligence quotient (IQ) was observed in these children. Possibly there is no threshold dose in this case. After exposure in the $9^{\text {th }}$ to $15^{\text {th }}$ week p.c. the decrease was about 30 IQ points per Sv, and between the $16^{\text {th }}$ and $25^{\text {th }}$ week p. c., about 10 IQ points per Sv.

A linear dose dependency without a threshold dose is generally assumed in cases of stochastic radiation damage In a large retrospective case-control study, an increase in malignant tumors and leukemia up to the age of 15 years was observed in children with prenatal radiation exposure [10].

Other studies show similar results. However, the data situation is very heterogeneous, partly because the interpretation of the available data is strongly based on assumptions. Based on the same data, for example, the additional probability of cancer mortality per dose for children under 10 years of age after intrauterine radiation exposure is given as $0.95 \%$ to $5.72 \%$ per Gy. The additional probability of tumor incidence per dose for children under 15 years of age is assumed to be $2 \%$ to $8 \%$ per Gy [11].

- Table 2 shows the probability of giving birth to a child who does not develop a malignant tumor as a function of the received intrauterine radiation dose. Only the risk associated with radiation exposure is considered and not a spontaneous malformation rate of about $3 \%$ [12].

Epidemiological data have not yet been able to demonstrate a clear increase in hereditary defects after prenatal radiation exposure, nor have they been able to rule this out [13]. In view of the relevant number of hereditary defects even without prenatal radiation exposure, the presumably comparatively small increase after radiation exposure is difficult to identify. It is therefore assumed in radiation protection analogous to the adult that there is no threshold dose for the induction of hereditary defects and
- Table 2 Dose-dependent probability of not developing a malignant tumor after intrauterine radiation exposure [8].

dose absorbed by the pre-
natal organism in addition to
natural radiation exposure,
expressed as uterine equi-
valent dose $\mathrm{H}_{\mathrm{U}}$
$\mathrm{H}_{\mathrm{U}} / \mathrm{mSv}$

dose-dependent probability of
not developing a malignant tumor
after intrauterine radiation
exposure (age 0 to 19 years)
$\mathrm{P} / \%$

\begin{tabular}{|l|l|}
\hline 0 to 5 & 99.7 \\
\hline 10 & 99.6 \\
\hline 50 & 99.4 \\
\hline 100 & 99.1 \\
\hline
\end{tabular}

there is a linear dose-response relationship in the range of small doses.

Animal experiments revealed risk coefficients of $0.0003 \%$ per $\mathrm{mSv}$ in men and $0.0001 \%$ per $\mathrm{mSv}$ in women for genetic anomalies in the first generation per live birth after prenatal radiation exposure of the gonads [5].

At doses above about $100 \mathrm{mSv}$, at least temporary infertility can occur in humans, which above about 1.5 Sv can become permanent [14]. Possible mutations in gametes above these doses therefore have no effect on offspring.

With exposures from about the 8th month on, organogenesis and development of the central nervous system are completed. Thus, only those deterministic and stochastic radiation risks are to be expected in the case of exposures that also occur in the exposure of newborns. Since exposures in later stages of pregnancy 
often no longer expose the entire unborn child in equal measure, it is advisable, as far as possible, to calculate the risks using organ equivalent doses of the exposed fetus.

The following two examples show the risks for individual radiation effects resulting from the dose of the unborn child.

\section{EXAMPLE 1 FOR THE ASSESSMENT OF RADIATION EXPOSURE}

The dose estimation resulted in a radiation exposure of the unborn child of $20 \mathrm{mSv}$. Since the dose is in a range in which no effects are expected, abortion during the pre-implantation phase, malformations and severe mental retardation should not be taken into account in this case (see $>$ Table 1 ). If the time of exposure was in the $9^{\text {th }}$ to $15^{\text {th }}$ week, this exposure would result in a decrease of the intelligence quotient by less than one IQ point on average. For children up to the age of 15 years, the risk that a malignant disease has been induced is calculated as between $0.04 \%$ and $0.16 \%$, corresponding to a likelihood between 1:2500 and 1:625. The risk of induction of hereditary defects resulting from exposure of a female fetus is $<0.002 \%$; this corresponds to a risk of $<1: 50000$. The risk of induction of hereditary defects resulting from exposure of a male fetus is $<0.006 \%$; this corresponds to a risk of $<1: 15000$.

\section{EXAMPLE 2 FOR THE ASSESSMENT OF RADIATION EXPOSURE}

If the dose estimate has indicated an exposure of the unborn child of $200 \mathrm{mSv}$ (i. e. $100 \mathrm{mSv}$ above the threshold), the risks for abortion during the pre-implantation phase and malformations must also be considered. When calculating the probability of occurrence of these effects, the risk coefficient can be applied to $100 \mathrm{mSv}$ (determined dose less the threshold) or $200 \mathrm{mSv}$ (determined dose), in which case the following risks arise:

- Exposure during the pre-implantation phase: the risk of zygote death before implantation is between 10 and $20 \%$;

- Exposure between the $3^{\text {rd }}$ and $8^{\text {th }}$ week: the risk of malformation lies between 5 and $10 \%$;

- Exposure between the $9^{\text {th }}$ and $15^{\text {th }}$ week: the probable reduction of the intelligence quotient is 3 to 6 IQ points;

- Exposure between the 16 th and $25^{\text {th }}$ week: the probable reduction of the intelligence quotient is 1 to 2 IQ points;

- The risk of induction of malignant disorders lies between $0.4 \%$ and $1.6 \%$;

- The risk of hereditary defects is in the order of $<0.06 \%$ (male) and $<0.02 \%$ (female).

These calculated risks are conservative estimates of the magnitude of the radiation risk, taking into account the gaps in the study data and the assumptions underlying these risk estimates

\section{Dose estimation procedure}

The organ equivalent dose in the patient's uterus is considered representative of the radiation exposure $H_{U}$ of the unborn child in the case of external irradiation. It is possible to estimate the exposure of the unborn child using two different methods:

- Step I: Estimation using exposure data and tables

- Step II: Estimation taking into account the examination parameters used and patient- and device-specific data.

- Fig. 1 shows the procedure as a flow chart for orientation regarding the further necessary steps.

First of all, the time of the radiation exposure post conceptionem is determined. If it is certain that the radiation exposure occurred up to 10 days p.c., no dose estimation is required, since any damage that may have occurred has either been repaired or no implantation has taken place.

If the radiation exposure took place after the $10^{\text {th }}$ day p. c., the estimation should first be carried out using exposure data and tables. Regarding fluoroscopic examinations, determination requires the time during which the uterus was in the direct radiation field. With projection radiographs, the number of images are required in which the uterus has been in the direct radiation field, as well as rough information about the patient's thickness. If no exact information is available, the upper estimate is to assume that the uterus was in the beam path during the entire fluoroscopy period. Using these values, conservative estimates for the dose $H_{U}$ can be calculated from $>$ Table 3, 4 [15].

\section{EXAMPLE OF UTERINE DOSE ESTIMATION FOR RADIOGRAPHY AND FLUOROSCOPY}

One patient (sagittal diameter: $20 \mathrm{~cm}$ ) underwent several examinations in the third week of pregnancy:

- two images of the thorax p.a. and lat.

- one image of the pelvis a.p.

- one image of the abdomen a.p.

- intraoperative fluoroscopy lasting 2 minutes, 0.5 minutes in the pelvic area.

Dose estimation

- According to $>$ Table 3: The uterus is in the direct beam path only during imaging of the pelvis and abdomen, therefore only these images are taken into account: 2 projection exposures with $3.0 \mathrm{mSv}$ each yields $6.0 \mathrm{mSv}$.

- According to - Table 4: Only the exposure time of the pelvis is considered: 0.5 minutes $24 \mathrm{mSv} / \mathrm{min}=12 \mathrm{mSv}$

Total dose: $6.0 \mathrm{mSv}+12 \mathrm{mSv}=18 \mathrm{mSv}$ Total dose is less than $20 \mathrm{mSv}$. A more precise estimation is not required.

If it is possible during computed tomography that the uterus was located in the effective radiation field, a conservative estimate is 


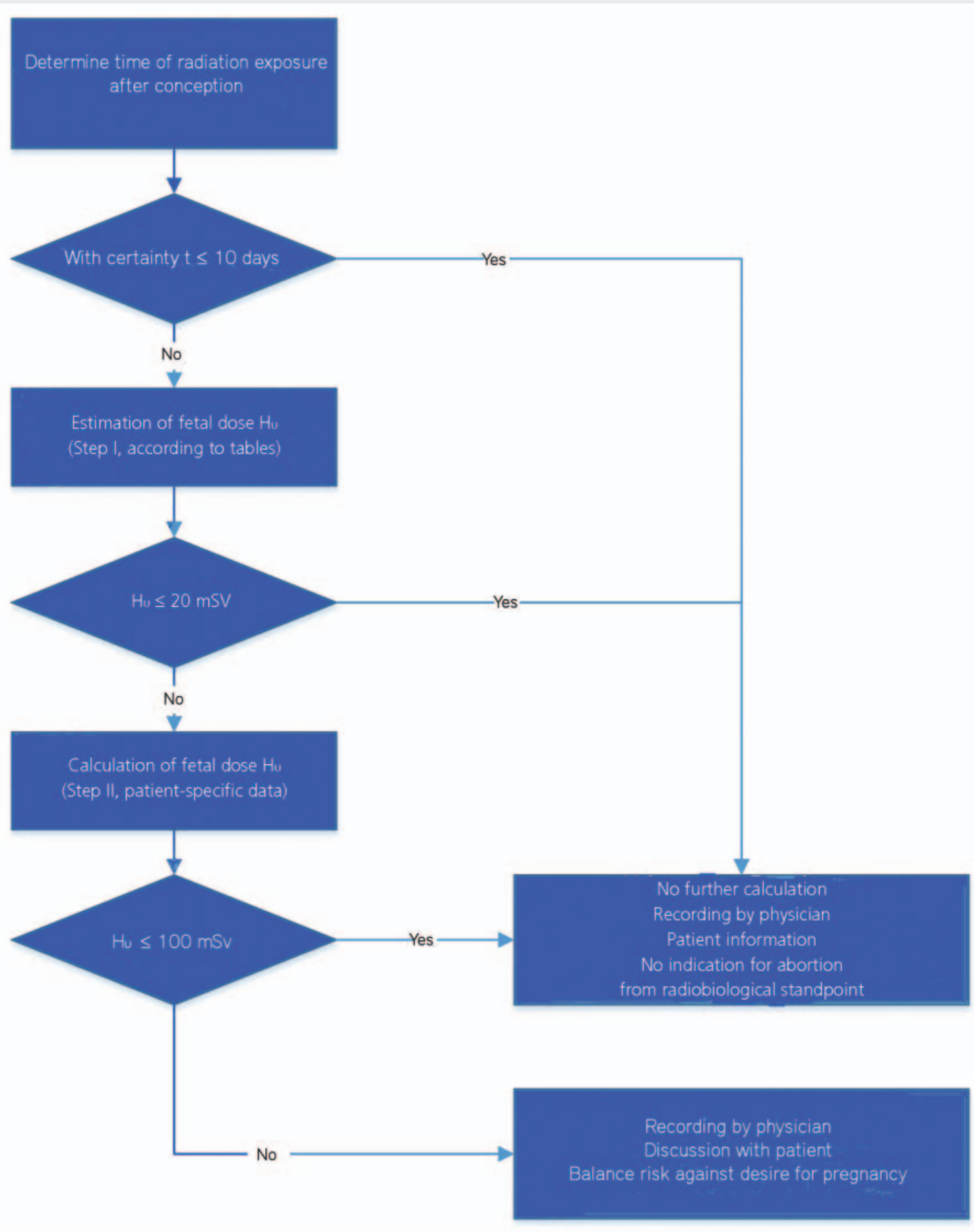

- Fig. 1 Flow chart for determining the equivalent dose of the unborn child $\mathrm{H}_{\mathrm{U}}$ (for external photon radiation $\mathrm{H}_{\mathrm{U}}$ corresponds to the uterine dose) after radiation exposure.

made based on the documented CTDIVol using the factors in - Table $5[16,17]$. The conversion factor $f$ from $>$ Table 5 should be selected according to the assumed position of the fetus and already takes into account that the mean $C T D I_{\text {vol }}$ is usually displayed in the patient protocol for long-range examinations and combination protocols (e. g. thorax and abdomen and pelvis). If there are several series (e. g. after administration of arterial and portal venous contrast agent), the values for the individual series must be added up accordingly. Calculation is based on

$H_{U}=f \cdot C T D I_{\text {vol }}$ 
- Table 3 Maximum organ equivalent dose values (conservative estimate) for the uterus for radiographs.

\begin{tabular}{|c|c|c|c|c|c|c|c|}
\hline \multirow{3}{*}{$\begin{array}{l}\text { Image type } \\
\text { constitution }\end{array}$} & \multicolumn{7}{|c|}{ Organ equivalent dose for the uterus per image/mSv } \\
\hline & \multicolumn{3}{|l|}{ a.p. } & \multicolumn{3}{|l|}{ p.a. } & \multirow{2}{*}{$\begin{array}{l}\text { lat. } \\
\text { normal } 36 \mathrm{~cm}\end{array}$} \\
\hline & thin $17 \mathrm{~cm}$ & normal $22 \mathrm{~cm}$ & thick $26 \mathrm{~cm}$ & thin $17 \mathrm{~cm}$ & normal $22 \mathrm{~cm}$ & thick $26 \mathrm{~cm}$ & \\
\hline projection image & 2 & 3 & 5 & 1 & 1.5 & 2.5 & 4 \\
\hline $\begin{array}{l}\text { images on fluoroscopy or } \\
\text { C-arm devices }\end{array}$ & 1 & 1.5 & 2.5 & 0.5 & 0.8 & 1.3 & 2 \\
\hline DSA image & 4 & 6 & 10 & 2 & 3 & 5 & 8 \\
\hline
\end{tabular}

- Table 4 Maximum organ equivalent dose rate values (conservative estimate) for the uterus during fluoroscopy.

\begin{tabular}{|c|c|c|c|c|c|c|c|}
\hline \multirow[t]{2}{*}{ Projection } & \multicolumn{7}{|c|}{ Organ equivalent dose for the uterus $1 \frac{\mathrm{mSV}}{\mathrm{min}}$} \\
\hline & \multicolumn{3}{|l|}{ a.p. } & \multicolumn{3}{|l|}{ p.a. } & \multirow{2}{*}{$\begin{array}{l}\text { lat. } \\
\text { normal } 36 \mathrm{~cm}\end{array}$} \\
\hline constitution & thin $17 \mathrm{~cm}$ & normal $22 \mathrm{~cm}$ & thick $26 \mathrm{~cm}$ & thin $17 \mathrm{~cm}$ & normal $22 \mathrm{~cm}$ & thick $26 \mathrm{~cm}$ & \\
\hline fluoroscopy & 16 & 24 & 40 & 8 & 12 & 20 & 32 \\
\hline
\end{tabular}

- Table 5 Rough conservative estimate of the uterine dose based on the value documented during the examination for the CTDIvol.

\begin{tabular}{|l|l|}
\hline uterus position & conversion factor to calculate $C T D I_{\text {vol }}$ to uterine dose $f / \frac{m S v}{m G y}$ \\
\hline partially or entirely in scan range & $1.5[15]$ \\
\hline adjoining, but safely outside of scan range & $0.2^{*}$ \\
\hline $\begin{array}{l}\text { safely far outside the scan range (e. g. skull, neck, lower distal } \\
\text { and upper extremities) }\end{array}$ & $<0.001$ \\
\hline & \\
\hline
\end{tabular}

\section{EXAMPLE OF A ROUGH ESTIMATION OF THE UTERINE DOSE FOR CT}

The CTDI ${ }_{\text {Vol }}$ shown in the dose report for an examination of the abdomen (sum of overview radiography, pre-monitoring, monitoring and scan) is $10.4 \mathrm{mGy}$. The uterine dose can thus be roughly estimated as:

$\mathrm{H}_{\mathrm{U}}=1.5 \mathrm{mSv} / \mathrm{mGy} * 10.4 \mathrm{mGy}=15.6 \mathrm{mSv}$.

As a rule, radiation exposure of the uterus remains below $20 \mathrm{mSv}$ in the vast majority of radiological examinations. A more careful consideration is necessary only if this dose is exceeded.

If the uterine dose is determined according to Step II, further, device-specific information is required, which is taken e. g. from the protocols of the acceptance test according to Section 115 of the Radiation Protection Ordinance. Furthermore, patient geometry and exposure conditions are considered individually or, in some rare cases, exposures are measured with appropriate phantoms. This requires knowledge of medical physics, therefore the calculation should be performed by the medical physics expert.

According to the source concept or image receiver concept, the incident dose $K_{E}$ can be determined and used to calculate the dose to the unborn child. The calculation of the dose to the unborn child can be carried out using three methods:

a) by means of examination-specific organ dose conversion fac-

tors and the use of the dose area product or the incident dose,

b) from the incident dose $K_{E}$ by means of the tissue-to-air ratio and the derived tissue absorbed dose in uterine depth and

c) from the incident dose or the radiation entrance surface dose by means of depth dose tables.

In CT examinations, a more precise estimation of the uterine dose is possible via the clearly differentiated conversion factors. The use of $C T D I_{\text {vol }}$ also eliminates the dependence of various pitch definitions by different manufacturers. 
Extensive tables and formulas must be used for a calculation according to Step II; these cannot be discussed in the context of this overview. The DGMP/DRG report [3] is available for more detailed information; this document describes the procedure in detail and contains further calculation examples. This report also discuses exposure in nuclear medicine and radiation therapy.

If dose levels to the uterus exceed $100 \mathrm{mSv}$, radiation exposure must be evaluated to determine the probabilities of congenital malformations, mental and developmental retardation, as well as mutagenic and carcinogenic effects (see Examples 1 and 2). In this case, a conversation with the patient is necessary in which the risks associated with radiation exposure are explained. These risks should be compared to the spontaneous risks for these possible effects to enable the patient to make a qualified assessment of the situation. The individual circumstances of the patient must also be taken into account when deciding whether termination of pregnancy should be performed; ultimately, the decision lies with the patient. The conversation with the patient should be prepared and, if necessary, carried out in an interdisciplinary consultation preferably consisting of the physician using the radiation, medical physics expert gynecologists, human geneticists and psychologists. It can often be helpful to involve a supra-regional expert, since dose values greater than $100 \mathrm{mSv}$ probably occur less than once per professional life and therefore there is seldom greater experience with such cases on site.

\section{Discussion}

If the dose to the fetus is less than or equal to $20 \mathrm{mSv}$, the risk of developing malformations including mental retardation is negligible. The risk of postnatal tumors associated with this exposure is so low that it is far below the risks normally associated with pregnancy. The value of $20 \mathrm{mSv}$ is well below the dose levels at which malformations and mental retardation are considered possible. These risks occur above $100 \mathrm{mGy}$ (corresponds to $100 \mathrm{mSv}$ for X-rays), see $>$ Table 1 . According to the two-step concept within the DGMP/DRG publication on prenatal radiation exposure, it is considered reasonable to work with simple tables (Step I) up to a determined dose of $20 \mathrm{mSv}$, but to perform a more differentiated estimation above that. The large difference has been chosen to account for the uncertainties associated with the tabulated dose coefficients. If the dose estimate for the unborn child is up to $20 \mathrm{mSv}$ (>95\% of cases [15]) according to Step I of the two-step concept, the physician prepares a protocol in which the results of the dose estimate are documented. In addition, it should be stated that the pregnant woman has been informed that there is no danger to the child resulting from radiation exposure. In this dose range there is no radiobiologically-based indication for pregnancy termination. It is well known that other medical disciplines occasionally hold conflicting views and that termination is recommended regardless of the existing professional basis. Here, the physician responsible for radiation exposure has the task of counteracting these conflicting views for the benefit of the pregnant woman and the developing child.

In the concrete case of prenatal radiation exposure, the indication of risks should help to estimate the probability of the occur- rence of various biological effects. This information can be taken into account when advising affected pregnant women in order to make recommendations for further action. The application and use of this information, among other things for advising pregnant patients, was comprehensively presented by Brent in 2009 [12].

At dose values above $100 \mathrm{mSv}$, termination is not completely out of the question from a radiobiological point of view; in these cases, further procedures should be clarified in an interdisciplinary consultation.

In the case of radiation exposure of pregnant women, it must be reviewed, as with other exposures, whether a significant event according to $\S 108$ of the Radiation Protection Ordinance [1] has occurred; however, exposure of an unborn child in itself does not result in an obligation to report an event.

\section{Conflict of Interest}

The authors declare that they have no conflict of interest.

\section{References}

[1] Strahlenschutzverordnung (StrlSchV): Bundesgesetzblatt Jahrgang 2018 Teil I Nr. 41, ausgegeben zu Bonn am 5. Dezember 2018.

[2] Deutsche Röntgengesellschaft. Diskussionsentwurf: Richtlinie für das ärztliche Verhalten nach Exposition der menschlichen Frucht mit ionisierender Strahlung und nach der Inkorporation radioaktiver Stoffe aus medizinischer Indikation. Fortschr Röntgenstr 1980; 132: 595-603

[3] Arbeitsausschuss zur Ermittlung der pränatalen Strahlenexposition der Deutschen Gesellschaft für Medizinische Physik e. V (2019) DGMP- und DRG-Bericht: Pränatale Strahlenexposition ausmedizinischer Indikation - Dosisermittlung, Folgerungen für die Ärztin/den Arzt und Schwangere, DGMP-Bericht Nr. 7., ISBN 978-3-00-064613-3. http://www.dgmp.de. Zugegriffen: 23.3.2020

[4] Gumprecht D, Kind A [Red.]. Wirkungen nach pränataler Bestrahlung. Veröffentlichungen der Strahlenschutzkommission. Band 2, 2. Aufl. Stuttgart, New York: Gustav Fischer Verlag; 1989

[5] UNSCEAR. Genetic and Somatic Effects of lonizing Radiation. New York: United Nations. 1986

[6] ICRP Publication 90. Biological Effects after Prenatal Irradiation (Embryo and Fetus). New York: United Nations. 1990

[7] Streffer C, Shore R, Konermann $G$ et al. Biological effects after prenatal irradiation (embryo and fetus). A report of the International Commission on Radiological Protection. Ann ICRP 2003; 33: 5-206

[8] ICRP Publication 84. Pregnancy and Medical Radiation. Annals of the ICRP. Vol. 30 No. 1 New York: Pergamon; 2000

[9] Otake M, Schull W], Lee S. Threshold for radiation-related severe mental retardation in prenatally exposed A-bomb survivors: a re-analysis. Int J Radiat Biol 1996; 70: 755-763

[10] Mole RH. Antenatal irradiation and childhood cancer: causation or coincidence? Br J Cancer 1974; 30: 199-208

[11] Wakeford R, Little MP. Risk coefficients for childhood cancer after intrauterine irradiation: a review. Int J Radiat Biol 2003; 79: 293-309

[12] Brent RL. Saving lives and changing family histories: appropriate counseling of pregnant women and men and women of reproductive age, concerning the risk of diagnostic radiation exposures during and before pregnancy. Am J Obstet Gynecol 2009; 200: 4-24

[13] UNSCEAR 2010 Report: Summary of low-dose radiation effects on health. New York: United Nations. 2010 
[14] Dörr W, Herrmann T. Prophylaxe von Fertilitätsstörungen nach Strahlentherapie. Onkologie 2005; 9: 58-60

[15] Deutsche Gesellschaft für Medizinische Physik und Deutsche Röntgengesellschaft, Bericht Nr. 7, Pränatale Strahlenexposition aus medizinischer Indikation. Dosisermittlung, Folgerungen für Arzt und Schwangere 2002 .
[16] Xie T, Poletti PA, Platon A et al. Assessment of CT dose to the fetus and pregnant female patient using patient-specific computational models. Eur Radiol 2018; 28: 1054-1065

[17] Stamm G, Nagel HD. CT-Expo - ein neuartiges Programm zur Dosisevaluierung in der CT. Fortschr Röntgenstr 2002; 174: 1570-1581 